\title{
Algicidal bacteria associated with blooms of a toxic dinoflagellate in a temperate Australian estuary
}

\author{
J. H. Skerratt ${ }^{1,2, *}$, J. P. Bowman ${ }^{1,2,3}$, G. Hallegraeff ${ }^{4}$, S. James ${ }^{5}$, P. D. Nichols ${ }^{1,2,6}$ \\ ${ }^{1}$ Antarctic Cooperative Research Center, ${ }^{2}$ Institute of Antarctic and Southern Ocean Studies (IASOS), ${ }^{3}$ School of Agricultural \\ Science, and ${ }^{4}$ School of Plant Science, University of Tasmania, Hobart, Tasmania 7005, Australia \\ ${ }^{5}$ School of Microbiology and Immunology, University of New South Wales, Sydney 2052, Australia \\ ${ }^{6}$ Commonwealth Scientific and Industrial Research Organisation (CSIRO) Marine Research Division, Hobart \\ Tasmania 7001, Australia
}

\begin{abstract}
Gymnodinium catenatum is an introduced toxic dinoflagellate that blooms intermittently and causes shellfish farm closure in the Huon Estuary, Tasmania, Australia. Seventy-five bacteria isolated from the estuary were tested for algicidal activity against this and other toxic and nontoxic algal species. Five isolates produced algicidal extracellular exudates. These algicidal species were a Pseudoalteromonas sp. (ACEM 4), a novel Zobellia sp. (ACEM 20), a strain of Cellulophaga lytica (ACEM 21) and 2 Firmicutes: a novel Planomicrobium sp. (ACEM 22) and a strain of Bacillus cereus (ACEM 32). This study is the first time Gram-positive bacteria have been associated with algicidal activities. Further data are presented on an algicidal Pseudoalteromonas species previously isolated from the Huon Estuary (Strain y). Supernatant produced by all 5 strains caused cell lysis and death in G. catenatum vegetative cells. No change or reversible ecdysis was noted for 2 other endemic dinoflagellate species. Algicidal or inhibitory activity was not activated via homoserine lactones, but bacterial quorum sensing for the isolates was shown by means of the AI-2 mechanism. Algicidal activity from field isolates was also influenced by strain or environmental variation. Bacteria were capable of losing or switching off their algicidal ability indicating that the presence of an algicidal species in the environment may not necessarily signify that they are currently algicidal. Concentrations of algicidal compounds required for algal lysis in laboratory experiments indicate that the 5 bacterial species can be effective against $G$. catenatum vegetative cells if they dominate the bacterial population in the estuary, particularly when attached to particles.
\end{abstract}

KEY WORDS: Algicidal · Gymnodinium • Pseudoalteromonas - Cellulophaga · Flavobacteria · Harmful algal blooms

Resale or republication not permitted without written consent of the publisher

\section{INTRODUCTION}

The Huon Estuary in Tasmania is an unpolluted waterway with low nutrient levels. Despite this, the estuary experiences periodic outbreaks of the introduced toxic dinoflagellate Gymnodinium catenatum that are detrimental to the local shellfish industry. An extensive 2 yr scientific study of the biology, chemistry and physics of the estuary confirmed the importance of physical forcing; however, no role for macronutrients

*Email: jenny.skerratt@utas.edu.au was obvious for this vertically migrating dinoflagellate (CSIRO Huon Estuary Study Team 2000).

The relationship between toxic algal blooms and algicidal bacteria has been the subject of extensive research (Stewart \& Brown 1969, Imai et al. 1993, Doucette et al. 1998, Lovejoy et al. 1998, Nagasaki et al. 2000). Particular attention has been paid to the potential use of algicidal bacteria in bloom control (Kim et al. 1998, Yoshinaga et al. 1999, Nagasaki et al. 2000). However, to date, no effective, practical use of these bacteria in the marine environment has been achieved.

Algicidal bacteria include various species in the genus Pseudoalteromonas as well as species of the 
Class Flavobacteria, predominantly the genus Cellulophaga (Doucette et al. 1998, Nagai \& Imai 1998). A Pseudoalteromonas strain previously isolated in the Huon Estuary demonstrated algicidal activity against Gymnodinium catenatum vegetative cells as well as other dinoflagellates and flagellates (Lovejoy et al. 1998). In the same study, another Pseudoalteromonas strain caused a detrimental but reversible effect on $G$. catenatum vegetative cells.

The mechanisms bacteria activate to produce algicidal components or to commence predatory attack are largely unknown. These mechanisms may include bacteria reaching a certain density before algicidal expression occurs (quorum sensing). This mechanism is typical of many bacteria that form biofilms but is also present in free-living bacteria (Schauder et al. 2001). Chemicals produced by bacteria such as acetylated homoserinelactones (AHL) can be used to communicate between bacteria in order to regulate expression (Bassler et al. 1993, Eberl 1999). Based on the concentration of AHL, bacteria activate or inactivate different functions that can regulate antibiotic production, conjugation, swarming, toxin production, biofilm formation, luminescence and exoprotease production (Bassler 1999, Eberl 1999). At certain AHL concentrations during midto late $\log$ phase, the receptor protein produces a phenotypic response and this is termed the threshold concentration. Many different bacterial species produce a signal molecule that is not an AHL but is termed an AI-2 inducer (Schauder et al. 2001) and thought to be significant for bacteria that exist in areas such as the marine environment where bacterial numbers are lower and species are diverse. Although AHL and AI-2 are different molecules they both use quorum sensing as the mode of control. Chemicals are used by bacteria to monitor their population density and could constitute possible regulatory mechanisms for the control of the expression of algicidal activity in the isolates. Algicidal isolates in this study were therefore tested for the 2 different types of signalling mechanisms, AHL and AI-2, that trigger luminescence in Vibrio harveyi, as well as the induction of many different genes (often involved in virulence) in a wide range of bacterial species.

The objectives of the present work were to screen a collection of cultured bacteria from the estuary and to identify the prevalence of algicidal activity against the toxic algal bloom species present in the estuary, Gymnodinium catenatum. The 5 positive bacterial isolates identified by this assay and their mode of action and activity against a wider range of organisms such as other dinoflagellates and diatoms was then examined. Implications of the presence of algicidal bacteria and evidence of whether complex control of expression and cell density influenced their algicidal expression was also investigated.

\section{METHODS}

Bacterial and algal strains studied. Over a 2 yr study of the Huon Estuary (August 1996 to September 1998), 5 biological stations were surveyed (CSIRO Huon Estuary Study Team 2000). The biological stations were part of a number of larger scale spatial surveys that included 40 sites throughout the estuary during different seasons. The biological stations were sampled frequently to resolve short-term changes and algal bloom behaviour. Bacterial isolates were collected from water samples from the Huon Estuary during this survey. Seventy-five bacterial isolates were catalogued as strains in the Australian Collection of Estuarine Microorganisms (ACEM). The algicidal activities of the 75 isolates were tested against the introduced toxic alga Gymnodinium catenatum using the procedure of Lovejoy et al. (1998). Genomic DNA was extracted from the cells of the algicidal isolates and purified using the procedure of Marmur \& Doty (1962). The 16S rRNA genes from these strains were amplified by PCR using the primers 10f (AGT TTG ATC CTG GCT CA) and 1492r (TAC GGY TAC CTT GTT ACG ACT T). Conditions used for PCR are described in Bowman et al. (1996). The 5 algicidal strains then underwent additional testing against other algal species (Table 1). Further data was also obtained on Strain y (referred to as ACEM 1), an algicidal Pseudoalteromonas species previously isolated from the Huon Estuary (Lovejoy et al. 1998).

Several other Pseudoalteromonas species, related to the 2 Huon Estuary Pseudoalteromonas strains (ACEM 1 and ACEM 4), were also tested for algicidal activity against Gymnodinium catenatum and Chattonella marina. The strains were $P$. espejiana (NCIMB 2127), $P$. rubra (NCIMB 1890), P. luteoviolacea (NCIMB 1893), P. citrea (NCIMB 1889) and P. aurantia (NCIMB 2033), 3 strains of $P$. piscicida (NCIMB 1938, 1142 and 645), $P$. tunicata (CCUG 26757) and P. ulvae (NCIMB 13762).

For maintenance of bacterial cultures, isolates were grown on marine agar (MA) using 11 Huon Estuary water adjusted to a salinity of 28 with artificial sea salts (MA:14 $\mathrm{g}$ agar, $5 \mathrm{~g}$ bacteriological peptone, $1 \mathrm{~g}$ yeast extract). For biocidal assays, MA using $28 \mathrm{~g}$ artificial sea salts and 11 distilled water was used in conjunction with an additional weaker nutrient media 1/10MA (salinity 28) in order that the nutrient levels were similar to those in the algal media.

Biocidal tests were carried out on the algal and microbial species listed in Table 1. Algal cultures were maintained at $17^{\circ} \mathrm{C}$ under cool white fluorescent light (100 photons $\mathrm{m}^{-2} \mathrm{~s}^{-1}$ ) and a 12:12 h light:dark cycle. Algal media used either $0.2 \mu \mathrm{m}$ filtered seawater or autoclaved $0.7 \mu \mathrm{m}$ filtered Huon Estuary water. Salinity was adjusted to 28 using Milli-Q deionised filtered water or the addition of artificial sea salts (Sigma). Dinoflagellate spe- 


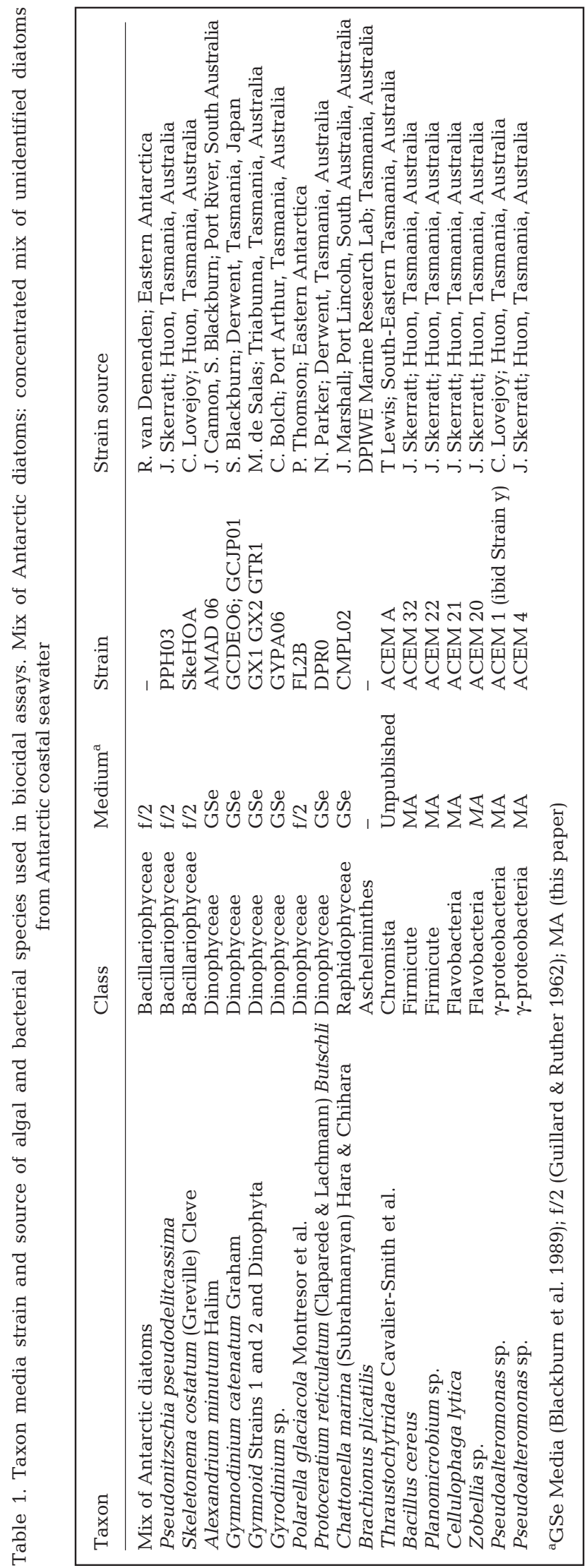

cies were grown in GSe medium (Blackburn et al. 1989). Other cultures were grown in media listed in Table 1 (Guillard \& Ryther 1962). Bacterial loads of the algal cultures were tested using both plate counts (CFU) and the fluorescent stain 4'6'-diamidino-2-phenylindole (DAPI, Sigma). All algal cultures tested were non-axenic, unialgal cultures with moderate to low bacterial loads $\left(10^{4}\right.$ to $10^{8}$ cells l $^{-1} \mathrm{CFU}, 10^{4}$ to $10^{9}$ cells $\mathrm{l}^{-1} \mathrm{DAPI}$ ).

Algal assays. The protocol described by Lovejoy et al. (1998) was used for algicidal assays. To test bacterial effects on different algal species, triplicate $1 \mathrm{ml}$ samples of algal culture were added to a 24 well microplate (Iwaki, Japan). To this, $100 \mu \mathrm{l}$ of a bacterial culture or filtrate or media control was added. Liquid media used for bacteria were MA and 1/10MA. Duplicate media controls were run in tandem with the experiments. The plates were sealed with parafilm and monitored at time intervals of $0,5,10,15,30,60,90,120$ and $180 \mathrm{~min}$ and then every hour for up to $6 \mathrm{~h}$. Cultures were then monitored daily. Most algal cultures lysed within $3 \mathrm{~h}$ once the algicidal bacteria or exudate was added. A positive algicidal effect was considered to occur when $80 \%$ or more algal cells were lysed. A dilution series was completed on the algicidal bacterial media added to the algal cells to determine bacterial concentrations required to produce algicidal lysis (Fig. 1).

Characterisation of algicidal bacteria and compounds. Specific growth rates of the bacterial isolates were determined to identify differences between algicidal activity in logarithmic and stationary phase cultures. Late log phase cultures $(1 \mathrm{ml})$ were inoculated into side arm flasks containing 1/10MA. Flasks were placed on a shaker table $\left(22^{\circ} \mathrm{C}, 120 \mathrm{rpm}\right)$ and growth curves were constructed by optical density measurements (OD: Absorbance $660 \mathrm{~nm}$ ). Sub-samples were taken every hour until the stationary phase commenced. To determine the specific growth rate, the natural logs (ln) of the optical density readings were plotted versus time for each culture. From the plot, the data points that best represented the logarithmic phase of growth were used to make a linear least squares fit (number of points on line $n=7$ to 10). From this equation, the slope was the calculated specific growth rate (Pirt 1975). Tests were carried out on the stability of the algicidal compounds with respect to temperature and the growth phase of the algicidal bacterial isolates. The algicidal abilities of the bacteria were tested in latent phase, early, mid- and late logarithmic phase, and early and late stationary phase. The heat stability of algicidal components was tested by incubating the bacterial supernatant (cell free) in enclosed Eppendorf tubes in a water bath at $38,55,80$ or $120^{\circ} \mathrm{C}$ (autoclave) for 30,15 and 10 min respectively.

Salinities and temperature ranges of the algicidal bacterial species were tested using MA broth. Tests on the effect of salinity changes were completed at $22^{\circ} \mathrm{C}$ 


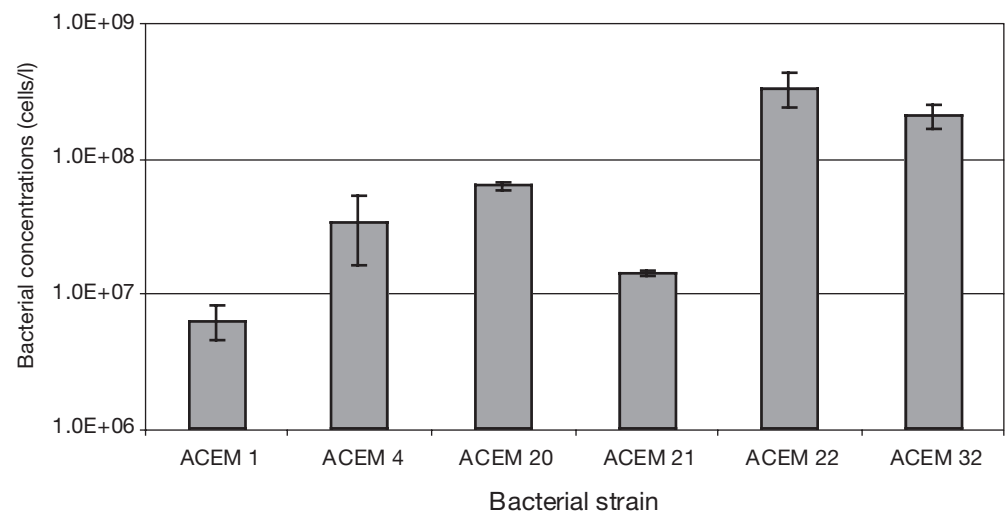

Fig. 1. Bacterial cell concentration (CFU) required to lyse Gymnodinium catenatum vegetative cells within $3 \mathrm{~h}$. The same numbers of bacteria were required independent of whether the addition included bacterial cells and filtrates oral bacterial filtrates alone

and tests on the effect of temperature changes were completed at a salinity of 28 . Observations of changes in the algicidal activity dependent on storage time and temperature were also observed during the course of the experiments.

Size fractionations of algicidal compounds were determined by placing the bacterial algicidal supernatant in dialysis tubing (5000 and $10000 \mathrm{amu}$ ) and completing biocidal tests after fractionation. Further separation of the algicidal compounds was achieved by HPLC using a Waters Alliance 2690 HPLC, coupled with a photo diode array detector, a reverse phase $\mathrm{C}_{18}$ column (Nova-Pak $\mathrm{C}_{18}, 3.9 \times 150 \mathrm{~mm}$ ) and a Finnigan LCQ with APCI source-vaporizer 450, capillary 170, sheath gas 60 , aux gas 15 , source current 5 Hamp or Finnigan LCQ with Electrospray source, capillary 200, sheath gas 90, aux gas 15, ESI needle $5 \mathrm{KV}$. The scan range was m/z 100 to 1200 (or m/z 100 to 2000 for the Electrospray source). Data-dependent MS-MS scans were collected from the most intense ions. The elution gradients included a gradient of water $-2 \%$ acetic acid-methanol at $0.8 \mathrm{ml} \mathrm{min}^{-1}$ or a 50:50 methanol:

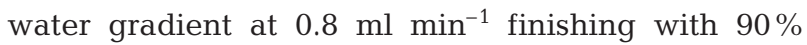
methanol at $25 \mathrm{~min}$. Fractions were collected and tested via assays using Gymnodinium catenatum. Controls were run using media blanks. All solutions were evaporated under gaseous nitrogen to dryness and adjusted with artificial sea water to double the equivalent volume added of the bacterial supernatant. These were then added to the algal cultures.

A normal phase cyano column (Nova-Pak CN HP, $3.9 \times 150 \mathrm{~mm}$ ) using a gradient of methanol (A), hexane (C) and water (D) at $0.8 \mathrm{ml} \mathrm{m^{-1 }}(95: 5 \% \mathrm{~A}: \mathrm{C}$ for $3 \mathrm{~min}$, $100 \%$ A for $30 \mathrm{~min}, 50: 50 \%$ A:D for $40 \mathrm{~min}$, which was then held for $20 \mathrm{~min}$ ) was used to separate fractions, which were then collected and tested against Gymnodinium catenatum.
All algicidal bacteria, except for ACEM 32 (Bacillus cereus strain), were highly pigmented. Extracted fractions containing bacterial pigment were tested for their algicidal activity because of these intense pigments and to eliminate them as a source of algicidal activity. Additionally, in the study by Egan et al. (2002), the bioactive activity of their bacteria varied in relation to pigment composition.

Algicidal bacteria were cultured in 1/10MA in $500 \mathrm{ml}$ conical flasks overnight at $18^{\circ} \mathrm{C}$. Pigments were extracted with acetone or methanol/dichloromethane. For acetone extraction, bacterial cells were filtered, the filters placed in $90 \%$ acetone, agitated ultrasonically for $5 \mathrm{~min}$, stored overnight at $-20^{\circ} \mathrm{C}$ and then resonicated, centrifuged and evaporated to dryness under gaseous nitrogen. Pigments were then solubilised with artificial seawater (salinity 28) and tested as below. The methanol/ dichloromethane extraction used the modified (White et al. 1979) 1-phase $\mathrm{CHCl}_{3}-\mathrm{MeOH}-\mathrm{H}_{2} \mathrm{O}$ Bligh \& Dyer (1959) method. After phase separation both the aqueous and organic layers were rotary evaporated at $35^{\circ} \mathrm{C}$ to dryness and the resultant pigments, dark purple and dark green, respectively, solubilised with sea water.

The resulting pigment extracts were made up to $1 \mathrm{ml}$ and $100 \mu \mathrm{l}$ aliquots were tested on Gymnodinium catenatum as indicated above. Extracts also contained unidentified compounds that co-extracted with the solvents used.

AHL assay. Algicidal bacteria were evaluated with an AHL bioreporter, based on the transcriptional activator TraR of Agrobacterium tumefaciens. TraR can respond to 3-oxo-AHL, 3-hydroxy-AHL and alkanoylAHL with chain lengths ranging from $\mathrm{C}_{4}$ to $\mathrm{C}_{12}$. The fusion reporter from the $A$. tumefaciens tumour inducing plasmid has been shown to be one of the most sensitive tests and versatile detectors of all AHL tests (Cha et al. 1998). AB minimal media was used (Clark \& Maaløe 1967) and plates were supplemented with $4.5 \mu \mathrm{ml}^{-1}$ tetracycline and $50 \mu \mathrm{g} \mathrm{ml}^{-1}$ spectinomycin, streaked with $A$. tumefaciens strain A136 and incubated at $30^{\circ} \mathrm{C}$. Fifty $\mathrm{ml}$ of $\mathrm{AB}$ media was inoculated with $A$. tumefaciens culture and incubated at $30^{\circ} \mathrm{C}$ for $24 \mathrm{~h}$. Molten $\mathrm{AB}$ agar media was cooled to $48^{\circ} \mathrm{C}$ and the $24 \mathrm{~h} \mathrm{~A}$. tumefaciens culture was then added. Wells were punched in the centre of each agar plate and $50 \mu \mathrm{l}$ of algicidal supernatant from 24 and $48 \mathrm{~h}$ cultures were added to the well. A positive control was included (Vibrio fischerii). The induced blue zone around the well was measured at 24 and $48 \mathrm{~h}$.

AI-2 assay. Protocols from Joyce et al. (2000) were used for the AI-2 assay. Confluent growth from $24 \mathrm{~h}$ 
algicidal bacteria plate cultures were collected by swabbing a plate flooded with $5 \mathrm{ml}$ of 1/10 MA broth. The swab was then inoculated into 1/10 MA broth to a starting optical density of 0.1 at $600 \mathrm{~nm}$, and incubated at $37^{\circ} \mathrm{C}$. Cell free culture fluids were prepared by centrifugation followed by filtration (Millipore $0.2 \mu \mathrm{m})$.

For the AI-2 assay, $10 \mu \mathrm{l}$ of each of the cell free cultures fluids were added to a 96 well microtiter dish (IWAKI) and assayed for AI-2 activity with strain Vibrio harveyi BB170 as described in Surette \& Bassler (1998, 1999). For each preparation, $10 \mu \mathrm{l}$ of the corresponding sterile medium was added to the wells as a negative control and $10 \mu \mathrm{l}$ of $V$. harveyi cell-free media was used as a positive control for AI-2 activity. V. harveyi BB170 was grown overnight with aeration at $30^{\circ} \mathrm{C}$ in $\mathrm{AB}$ medium then diluted 1:5000 in fresh $A B$ medium, and $90 \mu \mathrm{l}$ of the diluted culture was added to the wells containing the cell-free media or media controls. The microtiter dishes were shaken at $200 \mathrm{rpm}$ in a rotary shaker at $27^{\circ} \mathrm{C}$. Light production was quantified every hour with a Wallace Model 1450 Microbeta Plus liquid scintillation counter. Data are reported as the fold stimulation of light emission by $V$. harveyi BB170 over that obtained for the corresponding growth medium alone. Assays were performed in triplicate.

Algicidal activity of field bacteria. Seawater samples were taken from a site in the lower middle reaches of the estuary during the broader biological, physical and chemical study (CSIRO Huon Estuary Study Team 2000). The site chosen for this experiment was known for having high cell counts of Gymnodinium catenatum when this alga had bloomed in the previous 2 yr (Site F3: CSIRO Huon Estuary Study Team 2000). Water samples for the algicidal experiment were taken from the pycnocline (typically $2 \mathrm{~m}$ ) by means of a 51 Niskin bottle. These samples were plated onto MA and incubated at $22^{\circ} \mathrm{C}$ for $1 \mathrm{wk}$ to attain between 30 and 300 colonies for each sampling date. Colonies that were similar morphologically to ACEM 4, ACEM 1, ACEM 20, ACEM 21 and ACEM 22 were treated as bacteria with algicidal potential. After $1 \mathrm{wk}$ incubation at $22^{\circ} \mathrm{C}$, colonies were transferred to an Eppendorf tube containing 1/10MA. The cultures were incubated at $22^{\circ} \mathrm{C}$ for $2 \mathrm{~d}$. The bacterial suspensions were then centrifuged and a $100 \mu \mathrm{l}$ subsample of each of the supernatants was tested against G. catenatum using the previously mentioned algicidal assay.

Although identification of bacterial samples using morphological characteristics introduces bias with respect to the representation of the bacterial population, all algicidal colonies grew rapidly and well on MA and all had highly distinct morphologies as mentioned in 'Results'. Field samples had already been plated and collected every $2 \mathrm{wk}$ for $1 \mathrm{yr}$ prior to this experiment. A range of 16 to 89 (average 30) isolates were tested for algicidal activity for each field date. Although bacterial concentrations varied between sample dates similar bacterial types would reappear that were easily recognisable each week or each season. Algicidal activity was registered if cell lysis occurred within $3 \mathrm{~h}$.

\section{RESULTS}

\section{Characterisation of algicidal bacteria}

Five of the original 75 bacteria isolated from the Huon and deposited in the ACEM collection were algicidal and were phylogenetically identified (Table 1). The GenBank accession numbers of the 3 novel isolates investigated in this study were ACEM 4 (AF295592), ACEM 20 (AY035869) and ACEM 22 (AYO35870).

ACEM 4 was a strain or close relative of Pseudoalteromonas tunicata. ACEM 1 was closely related to Pseudomonas piscicida. ACEM 21 was a strain of Cellulophaga lytica, ACEM 32 was a strain of Bacillus cereus. ACEM 22 (Planomicrobium sp.) and ACEM 20 (Zobellia sp.) were 2 novel species whose closest relatives were Planococcus kocurii and Zobellia uliginosa, respectively. The genus Zobellia is very closely related to the genus Cellulophaga.

All 5 algicidal isolates, except ACEM 32, were highly pigmented and had distinct morphologies on solid media: ACEM 4 (Pseudoalteromonas sp.), dark green colonies and black media pigmentation; ACEM 1 (Pseudoalteromonas sp.), yellow colonies with white edges; ACEM 21 (Cellulophaga lytica), iridescent spreading orange colonies; ACEM 20 (Zobellia sp.), yellow-orange undulate colonies; and ACEM 22 (Planomicrobium sp.), round orange colonies and formed rods in logarithmic phase and cocci in stationary phase. All grew between 2 and $37^{\circ} \mathrm{C}$, except ACEM 4 which did not grow above $25^{\circ} \mathrm{C}$ and ACEM 22 which grew at $55^{\circ} \mathrm{C}$. All 5 algicidal isolates grew at salinities of 66 and only the 2 Firmicutes, ACEM 22 and ACEM 32, grew at salinities less than 5 .

Table 2. Generation time and specific growth rate of algicidal isolates (OD $660 \mathrm{~nm}$ and $22^{\circ} \mathrm{C}$ )

\begin{tabular}{|lccc|}
\hline $\begin{array}{l}\text { Algicidal } \\
\text { isolate }\end{array}$ & $\begin{array}{c}\text { Generation time } \\
(\mathrm{min})\end{array}$ & $\begin{array}{c}\text { Specific growth } \\
\text { rate }(\mu)\end{array}$ & $\mathrm{r}^{2}$ \\
\hline ACEM 1 & 7.49 & 7.72 & 0.931 \\
ACEM 4 & 7.64 & 7.56 & 0.975 \\
ACEM 20 & 9.15 & 6.31 & 0.996 \\
ACEM 21 & 10.21 & 5.66 & 0.997 \\
ACEM 22 & 7.39 & 7.82 & 0.996 \\
\hline
\end{tabular}


Table 3. Comparison of bacterial growth stage and the effect of algicidal activity on Gymnodinium catenatum vegetative cells

\begin{tabular}{|c|c|c|c|c|c|c|}
\hline \multirow[t]{2}{*}{ Growth phase } & \multicolumn{6}{|c|}{ Algicidal isolate } \\
\hline & ACEM 1 & ACEM 4 & ACEM 20 & ACEM 21 & ACEM 22 & ACEM 32 \\
\hline Latent and early log & - & - & - & - & - & - \\
\hline Mid-log & $\begin{array}{l}50 \% \text { cell } \\
\text { lysis and cell } \\
\text { rounding }\end{array}$ & $\begin{array}{l}10 \text { to } 30 \% \text { cell } \\
\text { lysis and cell } \\
\text { rounding }\end{array}$ & $\begin{array}{l}<10 \% \text { cell } \\
\text { lysis and cell } \\
\text { rounding }\end{array}$ & $\begin{array}{l}10 \text { to } 30 \% \text { cell } \\
\text { lysis and cell } \\
\text { rounding }\end{array}$ & $\begin{array}{l}10 \text { to } 30 \% \text { cell } \\
\text { lysis and cell } \\
\text { rounding }\end{array}$ & - \\
\hline Stationary & $100 \%$ cell lysis & $100 \%$ cell lysis & $\begin{array}{c}\geq 80 \% \text { lysis and } \\
\text { cell rounding }\end{array}$ & $\begin{array}{l}\geq 90 \% \text { lysis and } \\
\text { cell rounding }\end{array}$ & $\begin{array}{c}\geq 80 \% \text { lysis and } \\
\text { cell rounding }\end{array}$ & $\begin{array}{c}\geq 80 \% \text { lysis and } \\
\text { cell rounding }\end{array}$ \\
\hline
\end{tabular}

Rapid growth rates and generation times were observed for all algicidal bacteria (Table 2). Specific growth rates were high (Table 2) and generation times were 7 to $10 \mathrm{~min}$. The growth rate of ACEM 32 (Bacillus sp.) is not presented as colloidal balls formed, making it difficult to accurately measure optical density.

No bacteria were algicidal in latent or early log phase (Table 3). All bacteria, except ACEM 32, were algicidal during mid-log phase and early and late stationary phase. ACEM 32 reached late log phase at 10 to $14 \mathrm{~h}$; production of algicidal components in ACEM 32 occurred after 20 h. Therefore, ACEM 32 was only algicidal in stationary phase.

\section{Specificity of algicidal isolates}

Algicidal supernatants of the bacteria were tested on a range of algal and heterotrophic species previously used in studies of algicidal bacteria (Table 4). The main algal species of interest was Gymnodinium catenatum as this was the toxic alga that commonly bloomed in the Huon Estuary.

Previously the methods of bacterial algicidal attack have been described as 'direct' and 'indirect' (Doucette et al. 1998). 'Direct' indicates that physical contact is required between the bacteria and the algal cell before the algal cell lyses and 'indirect' indicates that the bacteria exudes the lysing compound into the surrounding media or water column (Doucette et al. 1998). Hence, detection of the direct attack required the presence of bacterial cells and indirect attack was ascertained by adding only the filtrate or exudate from the bacterial medium.

Algicidal components produced by all 5 bacterial strains were extracellular and therefore the strains primarily used indirect attack. Algicidal lysis started within 15 min of adding the filtered supernatant to the dinoflagellate culture and total lysis usually occurred within $2 \mathrm{~h}$. Bacterial numbers required for algal lysis were generally between $10^{6}$ and $10^{10}$ cells $1^{-1}$ (Fig. 1). Numbers were the same whether filtrate or filtrate plus bacterial cells were added.
The mode of lysis using extracellular compounds was similar for all algicidal bacteria and to published data for strain ACEM 1 (Lovejoy et al. 1998). After 2 to 15 min, chain-forming species such as Gymnodinium catenatum (Fig. 2a) would separate into single cells (Fig. 2b). Fig. 2c shows a single unrounded cell of $G$. catenatum still unaffected by exposure to the algicidal component surrounded by other rounded algal cells. During the period of cell rounding, some cells would not become rounded for up to $1 \mathrm{~h}$, whereas others would start to lyse. Occasionally large temporary cysts would form in cultures that contained algicidal bacteria and these would also eventually lyse. Within 30 to 45 min, single cells would start to show cell rounding and thinning of the cell wall (Fig. 2c) followed by lysis of the cell wall after 1.5 to $4 \mathrm{~h}$ (Fig. 2d). When bacterial cells from ACEM 1 and ACEM 21 were added with their algicidal supernatant, vigorous bacterial swarming was observed around the algal cell once the alga had began to lyse (Fig. 2d).

All bacterial supernatants, except ACEM 20 and ACEM 22, lysed the vegetative forms of the toxic algae Gymnodinium catenatum, Chattonella marina and Alexandrium minutum. ACEM 20 and ACEM 22 did not lyse $A$. minutum but lysed $G$. catenatum and $C$. marina. No effect of algicidal activity was observed on any of the diatom, rotifer or thraustochytrid species tested.

Algicidal activity against 4 Tasmanian dinoflagellates was tested (Tables $1 \& 4$ ). One armoured dinoflagellate species, Protoceratium reticulatum, was unaffected by any of the algicidal bacteria and no cells lysed or rounded. The algicidal components of both Pseudoalteromonas species were detrimental towards 3 dinoflagellate species, however, one of these species (Gyrodinium sp.) recovered and survived after treatment. Some cells lysed or rounded; however, the unlysed Gyrodinium cells eventually recovered normal movement and further lysis did not occur. The other algicidal strains were not as effective at lysing the dinoflagellates as ACEM 1 and ACEM 4 (Pseudoalteromonas sp.), and had no effect on the Dinophyta species. They also had no effect on Gyrodinium except 


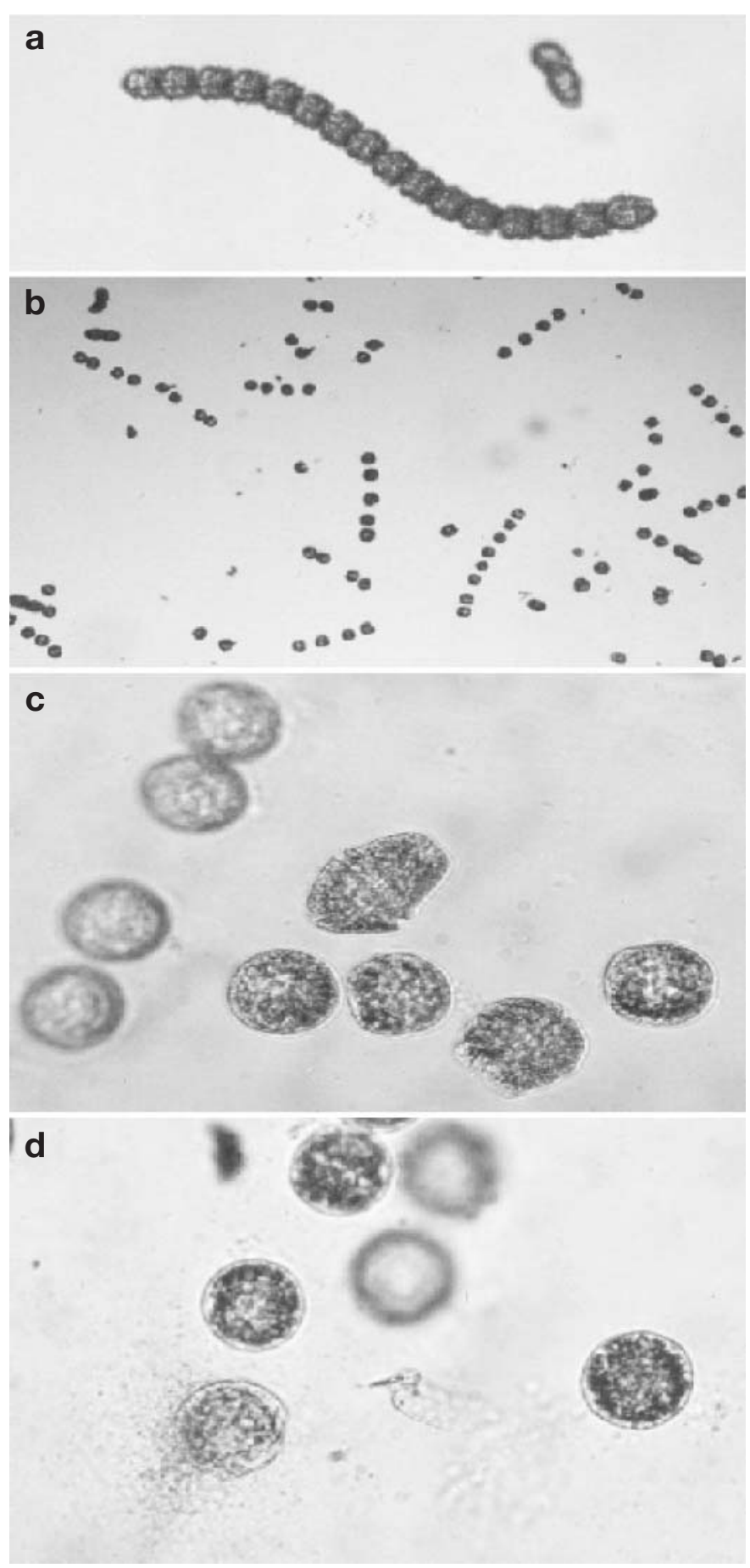

Fig. 2. Gymnodinium catenatum. Images showing time series of vegetative cells after addition of algicidal supernatant from ACEM $1(\mathrm{a}, \mathrm{b}, \mathrm{c})$. The addition of algicidal bacteria (ACEM 1$)$ is shown in (d) to demonstrate swarming affect of this bacteria. Similar lysis of the cell wall is noted with the addition of supernatant alone

ACEM 21 (Cellulophaga lytica). ACEM 21 caused some lysis and cell rounding but the Gyrodinium species survived.
Of the additional Pseudoalteromonas species tested for algicidal activity against Chattonella marina and Gymnodinium catenatum, only Pseudoalteromonas rubra, $P$. tunicata and $P$. ulvae lysed the 2 toxic algal species.

ACEM 21 produced extracellular exudates that were capable of lysing the algae, but the bacteria also demonstrated the ability to attack the algal cells directly. We also confirmed previous descriptions of the ability of ACEM 1 to directly attack algal cells (Lovejoy et al. 1998) although this was most apparent once the algal cells had started leaking (20 to $60 \mathrm{~min}$ ), and bacterial cells were highly concentrated and physically active around these leakage areas. This swarming behaviour was apparent to the degree that the algal cells were physically moved around the field of view by the bacterial swarm. The swarming effect was not apparent if the supernatant was added alone, but cell lysis occurred within a similar time frame. If bacteria were added with the supernatant, faster mechanical disintegration of cells was observed in all cultures apart from those with ACEM 22 added. The physical breakdown of the algal cells appeared to allow the bacterial swarm to become more effective once the integrity of the algal cell wall was broken.

\section{Stability and loss of algicidal activity}

The algicidal activity of the filtered supernatant for the Pseudoalteromonas species ACEM 1 and ACEM 4 remained unchanged after a week at room temperature $\left(23^{\circ} \mathrm{C}\right), 1$ to $3 \mathrm{mo}$ at $4^{\circ} \mathrm{C}$ or $6 \mathrm{mo}$ at $-20^{\circ} \mathrm{C}$. Noticeable deterioration was observed for longer periods. After $12 \mathrm{mo}$, algicidal activity had disappeared for samples at $4^{\circ} \mathrm{C}$ and was very poor $(<10 \%$ lysis $)$ at $-20^{\circ} \mathrm{C}$.

The ability to retain algicidal activity after heat treatment was also tested. All supernatants were algicidal after $30 \mathrm{~min}$ at $38^{\circ} \mathrm{C}, 15 \mathrm{~min}$ at $55^{\circ} \mathrm{C}$, $10 \mathrm{~min}$ at 80 or $120^{\circ} \mathrm{C}$ (autoclave). The mode of algal lysis appeared to be the same as before heating, i.e. it did not appear to be a toxic artefact caused by heating. Overall, this indicates that the algicidal mechanism in each of the bacteria was not enzymatic.

Algicidal bacteria would occasionally lose their ability to lyse algal cells completely. This occurred sporadically for all bacteria except ACEM 21 (Cellulophaga lytica). The loss of algicidal activity was often restored by isolation of a healthy bacterial colony into seawater for 1 or $2 \mathrm{mo}$ at $20^{\circ} \mathrm{C}$. ACEM 22 (Planomicrobium sp.) often lost activity after being cryo- 
genically stored. The algicidal revival method mentioned was used twice successfully for ACEM 22. However, for a period of over $1 \mathrm{yr}$, it would not recover any algicidal activity. The addition of the spent, filtered supernatant of another algicidal bacteria to ACEM 22 (A. Franks pers. comm.) was eventually used to reinitiate algicidal activity in ACEM 22. This method was also tested for Escherichia coli and other environmental strains to identify the possibility of initiating activity in species that were not algicidal, but this did not occur.

Algicidal activity could be lost in ACEM 1 once the culture had been continuously agitated for 3 to $4 \mathrm{~d}$. After this period, the media would appear clear, as though no growth had occurred. Autolysis was a possible cause of this phenomenon. The algicidal activity of this broth was severely affected and became equivalent to the culture in early log phase. The other algicidal isolates did not exhibit autolysis when grown under similar conditions.

Algicidal activity varied dramatically for bacterial isolates taken from the estuary at different sampling dates that were identified as strains of algicidal species (algicidal-like). Up to $90 \%$ of the algicidal-like isolates were algicidal for 1 date, yet similar isolates in the following weeks showed no such activity (Fig. 3). Interestingly, many algicidal-like isolates were not 'algicidal' at the peak of a Gymnodinium catenatum bloom even though they were present before and after the bloom declined.

Algicidal-like isolates were present on each of the sampling dates and, although the proportions of the isolates changed, similar species were observed in

Table 4. Mode of attack of algicidal bacteria against host species. Bold text indicates results for this study, other results are previously published; *indigenous Tasmanian algal species. D: direct attack or attachment onto algal cell causing lysis of host; I: indirect attack (bacterial algicidal exudate) causing lysis of host; IR: indirect attack with some cells lysed but eventual recovery of unlysed host cells. ne: no effect. Table adapted from Doucette et al. (1998)

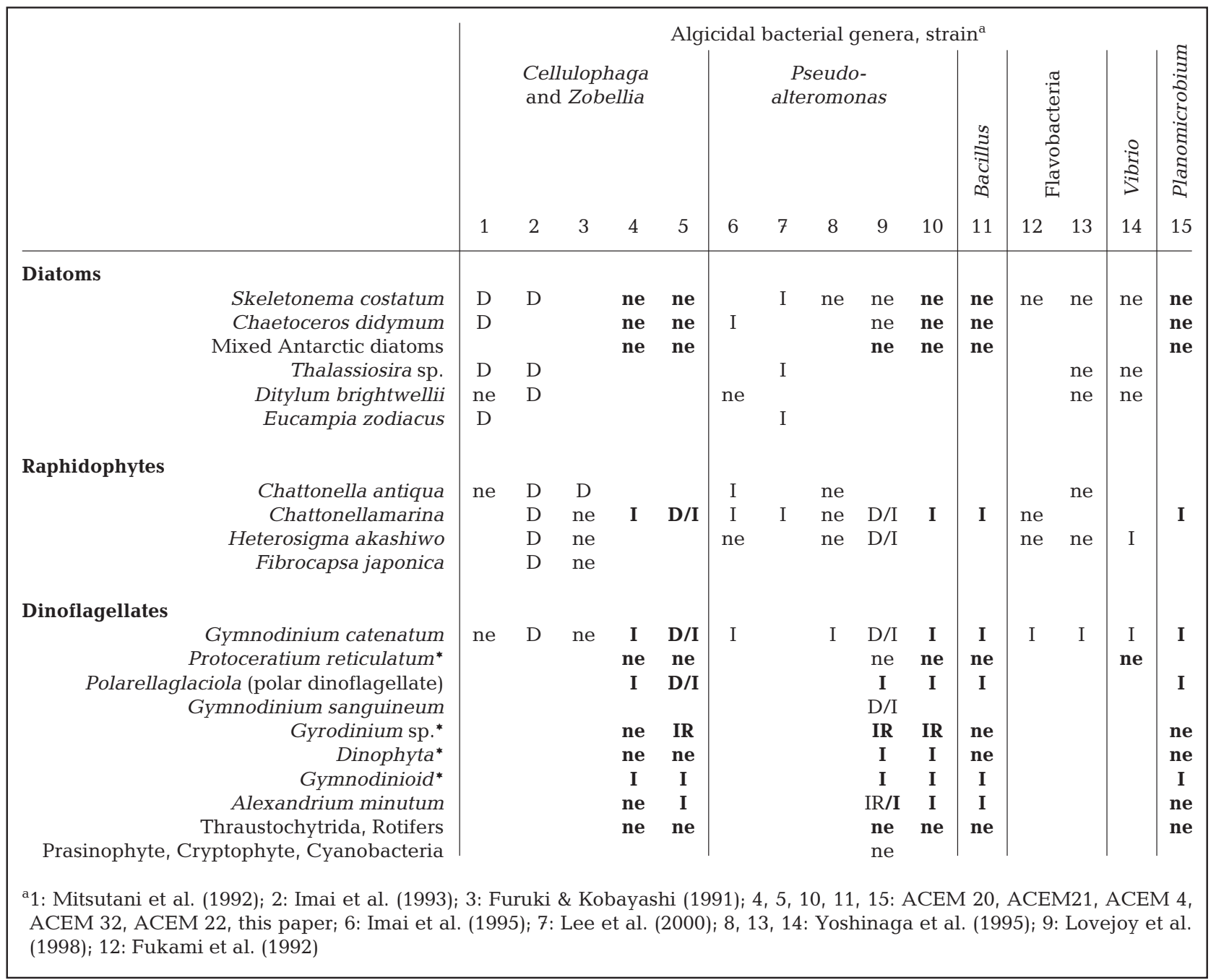




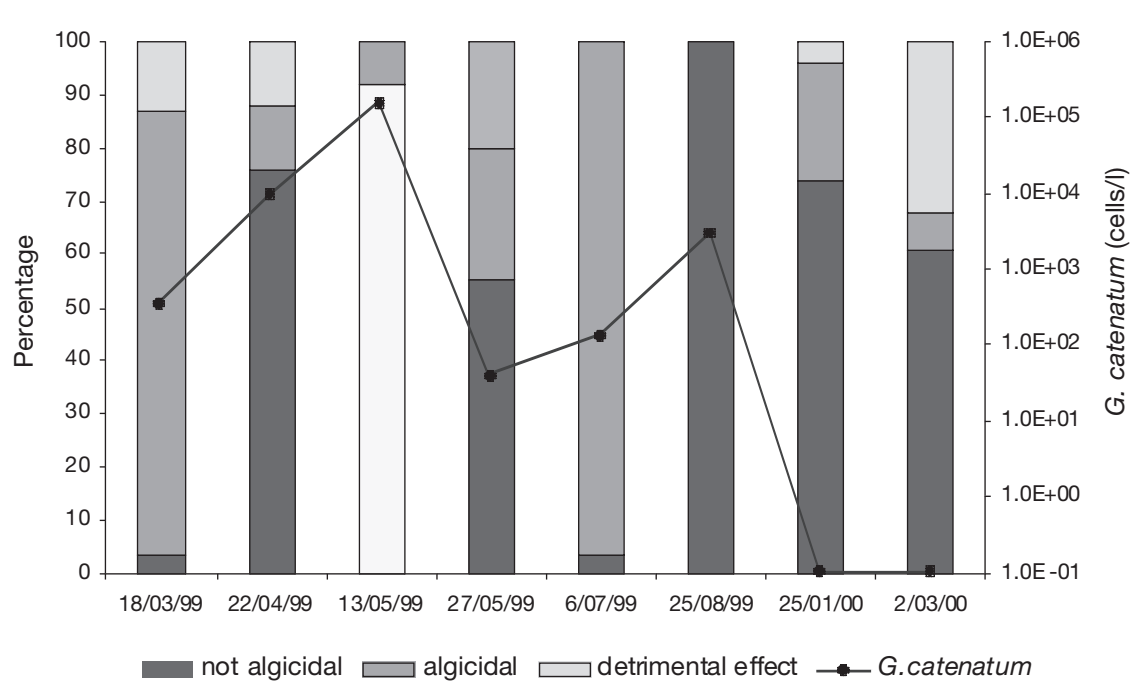

Fig. 3. Algicidal-like bacteria isolated from the Huon River, Tasmania, over 1999-2000 season and their algicidal activity for particular dates compared with Gymnodinium catenatum vegetative cell numbers (G. catenatum counts; Parker 2002). Detrimental effect was algal cell rounding but later recovery

lished that the compounds were highly polar and of low molecular weight. The algicidal compounds eluted in the first 2 min of the elution gradient (water) using the $\mathrm{C}_{18}$ reverse phase column. HPLC analysis with the normal phase column resulted in the compounds being retained on the column. Use of ion exchange chromatography, Sephadex columns and XAD columns were unsuccessful in isolating and/or concentrating these fractions.

\section{Quorum sensing}

The tests to determine the presence of AHL were negative for all algicidal species. The Agrobacterium tumefaciens TraR test is the most sensitive for detection of AHL and the result suggests that the typical pathway for gene

consecutive weeks. These species also varied in their algicidal activity. For example, the spreading iridescent orange ACEM 21-like isolate was algicidal whenever present. In comparison, Gram-positive ACEM 22like orange isolates that occurred at the peak of the Gymnodinium catenatum bloom were not algicidal at this time, although similar isolates in the weeks before and after were algicidal.

\section{Characterisation of algicidal components}

The pigment-containing fractions of algicidal strains did not possess algicidal activity. Colony pigmentation of both Pseudoalteromonas species ACEM 1 and ACEM 4 could be altered using different media, a typical characteristic of Pseudoalteromonas. Occasionally, ACEM 1 and ACEM 4 produced non-pigmented variants that co-occurred with their respective yellow or green colonies. The non-pigmented variants were not a contaminant as they reverted back to yellow and green colonies, respectively, if replated. If the nonpigmented variants were repeatedly replated for a number of generations ( $\mathrm{n}=4$ to 10 ), algicidal activity in ACEM 1 and ACEM 4 continued to occur. Changes in pigmentation did not appear to affect the algicidal activity. Pigment formation in these isolates was therefore not essential to the algicidal activity of the isolates, but all isolates had the ability to produce pigment as part of their cell biochemistry.

Algicidal components of ACEM 1 and ACEM 4 were less than 5000 amu. Analysis by HPLC-MS-MS estab- regulation via AHL does not induce the algicidal or other bioactive mechanisms in these species.

The second form of regulatory expression tested was AI-2. AI-2 uses similar regulatory expression as for the production of AHL. Vibrio harveyi BB170 was used to test for this second mechanism of quorum sensing control. The algicidal strains all showed some activation of lux genes in comparison to the negative control (Fig. 4). In particular, strong signals were observed for Firmicute isolates ACEM 22 and ACEM 32, respectively; ACEM 22 at late and mid-log phase, and ACEM 32 at late log phase. ACEM 20 and ACEM 1 demonstrated activity for all growth phases. The results indicate that for the algicidal Gram-negative species the bacteria appear to use the AI- 2 mechanism at mid- to late stage of log phase.

\section{DISCUSSION}

All algicidal species investigated in this study employed indirect or extracellular methods of lysing algal cells. Two isolates (1 previously described in Lovejoy et al. 1998) also used direct attack or attachment to the algal cell. To date, only a few algicidal bacteria have been isolated that attack diatom species (Table 4; Mitsutani et al. 1992, Imai et al. 1993, Lee et al. 2000). Of these 3 studies, 2 were direct attacks by Cellulophaga species and one involved a protease produced by a Pseudoalteromonas strain. Proteases are usually not heat tolerant, so it is unlikely that the 
Pseudoalteromonas from the Huon Estuary used this method to lyse algal cells.

In contrast to species algicidal towards diatoms, dinoflagellates and flagellates have demonstrated particular sensitivity to the algicidal components of bacteria (Table 4). Interestingly the native Tasmanian dinoflagellates in this study appeared less affected overall by the bacterial exudates. Unlike Gymnodinium catenatum, which is an introduced species, it is possible that these native algal species may have some resistance to the resident algicidal bacteria. However, further research is necessary to determine if this proposition is of significance.

To our knowledge, Lovejoy et al. (1998) is the only previously published work to mention the effect of algicidal species against higher order organisms (Table 4). The 5 algicidal isolates in this study also demonstrated no effect on Thraustochytrida or rotifers indicating low level classspecific effects.
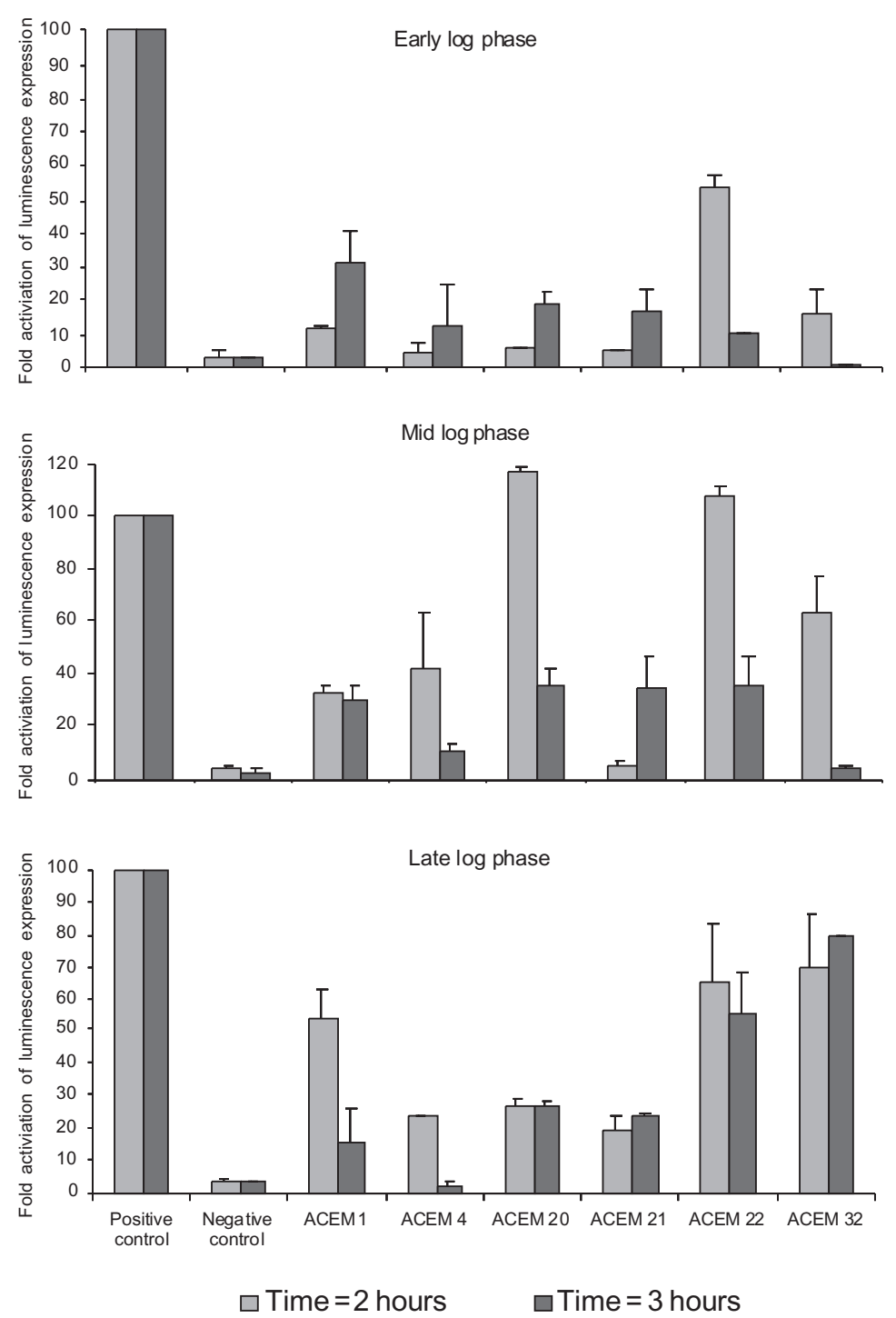

Fig. 4. Time series of algicidal strains at different growth phases, showing induction of the luminescence gene via the autoinducer mechanism AI-2. $y$-axis shows activity, reported as fold activation of luminescence of the algicidal strains over the level of luminescence when sterile media was added. Luminescence $(n=3)$ is reported with respect to the positive control. Positive control: luminous bacterium Vibrio harveyi. At and after $4 \mathrm{~h}$, the negative control becomes positive; therefore, results after $3 \mathrm{~h}$ are not shown
Flavobacteria

Cellulophaga are one of the most prolific and widely studied algicidal genera (Stewart \& Brown 1969, Imai et al. 1991, 1993, Mitsutani et al. 1992, Yoshinaga et al. 1998, Kondo et al. 1999, Toncheva-Panova \& Ivanova 2000). The genus Cellulophaga and the Class Flavobacteria can dominate many marine systems and are often associated with marine snow and the decay of algal blooms (Delong et al. 1993, Crump et al. 1999, Riemann et al. 2000). They grow easily in oligotrophic conditions as they can utilise a variety of carbon sources for growth, but can also thrive on nutrient-rich media such as marine snow or enriched environmental conditions. They are found throughout the water column of temperate and polar marine environments (Glöckner et al. 1999, Cottrell \& Kirchman 2000, Pinhassi \& Hagström 2000, Fandino et al. 2001) and are common in fresh water where they have also demonstrated swarming and predatory algicidal abilities (Stewart \& Brown 1969). Pinhassi \& Hagström (2000) reported the domination of a coastal community by Flavobacteria during a coastal phytoplankton decline (43\% of intact cells). A study by Glöckner et al. (1999) demonstrated that members of the Class Flavobacteria were the most abundant group detected in a number of different marine systems, accounting for an average of $18 \%$ ( 2 to $72 \%$ ) of the DAPI stained cells.

ACEM 20 and ACEM 21 are both members of the Flavobacteria and their algicidal activity differed to that previously described for most other members of this class (Imai et al. 1993, 2001). Gliding bacteria typically attach directly to a cell (direct attack) rather than useing extracellular compounds (indirect attack). In other studies of algicidal Cel- 
lulophaga-like species, all but one have shown predatory mechanisms only (Table 4). Recently, another Cellulophaga-like species unrelated to the 2 described in this study (89\% 16S rDNA sequence similarity to ACEM 20, G. Doucette pers. comm.) was reported as using extracellular mechanisms and indirect attack. Both Flavobacteria in this study produced an algicidal exudate. In the case of ACEM 21 , this was in addition to a predatory mechanism of physically attacking the cells.

\section{Pseudoalteromonas}

Pseudoalteromonas is the second most abundant and commonly reported genus of algicidal bacteria after Cellulophaga (Baker \& Herson 1978, Imai et al. 1995, Lovejoy et al. 1998, Lee et al. 2000). Lysing occurs through the indirect method of extracellular exudation, and they have previously shown species-specific algicidal activity (Lovejoy et al. 1998). They also have the ability to lyse cells and swarm using their flagella once the cells are leaking (Imai et al. 1995, Doucette et al. 1998, 1999). The most highly studied species of this genus to date is Pseudoalteromonas tunicata which produces at least 3 different bioactive compounds that act independently: antifungal, inhibition of algal spore germination and antifouling (Holmström \& Kjelleberg 1999, Egan et al. 2000). P. tunicata is closely related to ACEM 4.

Pseudoalteromonas rubra, P. ulvae and P. tunicata were the only other Pseudoalteromonas species of 8 tested that possessed the same algicidal activity against Gymnodinium catenatum and Chattonella marina as the 2 Pseudoalteromonas in this study (ACEM 1 and ACEM 4). Pseudoalteromonas are known for their many bioactive compounds (Gauthier 1976, Mikhailov \& Ivanova 1994). Other Pseudoalteromonas species tested such as P. luteoviolacea (McCarthy et al. 1994), P. aurantia (Gauthier \& Breittmayer 1979) and P. piscicida (Buck et al. 1963) have all produced antibacterial or bioactive compounds. In our study, these species did not demonstrate any algicidal activity. Given the nature of these algicidal components our results suggest some of the bacterial strains stored in culture collections may have lost activity over time. Other workers examining this genus have also found a lack of any bioactivity in many of the species (C. Holmström pers. comm.).

Lysis of Alexandrium minutum by ACEM 1 (Pseudoalteromonas sp.) in this study was in contrast to the study by Lovejoy et al. (1998) in which ACEM 1 caused A. minutum cells to round but recover after $24 \mathrm{~h}$. The variation between the 2 studies may be due to the maintenance of bacterial cultures in this study on MA before completion of the biocidal assays on 1/10MA. In the experiment by Lovejoy et al. (1998), ACEM 1 was maintained at 1/10MA.

\section{Firmicutes}

ACEM 22 (Planomicrobium sp.) and ACEM 32 (Bacillus cereus) represent the first description of Grampositive species that produce algicidal components. The $B$. cereus group produces many extracellular compounds that include haemolysin, a soluble toxin lethal for mice, insecticidal toxin, phospholipase $\mathrm{C}$ and bacterial-lytic and proteolytic enzymes (Claus \& Berkeley 1989, Lereclus 2000). B. mycoides, a closely related species to ACEM 32, has shown bioactive properties that have been used in the agriculture and biomedical industries (Hammad \& El-Mohandes 1999, Pruss et al. 1999), and can be the causative agent in agricultural infections (Grodnitskaya \& Gukasyan 1999). Most of the toxins and bioactive compounds in the $B$. cereus group are only produced in stationary phase (Lereclus 2000). In this study, ACEM 32 only produced algicidal exudates in stationary phase and not in log phase.

The genus Planomicrobium is closely related to the Bacillus cereus group, but is essentially a marine genus with no previously reported pathogenicity or algicidal abilities. The Planomicrobium isolate, ACEM 22 , was the only species that did not show swarming activity. Although fast growing, the algicidal ability of ACEM 22 after being kept in culture for long periods of time was highly intermittent when compared with the other algicidal isolates.

The 2 Firmicutes were also unusual because most algicidal bacteria are of Class Flavobacteria or the genus Pseudoalteromonas. It is possible that to date descriptions of algicidal species have been influenced by bacterial culturability.

\section{Quorum sensing}

The association with and potential for control of toxic algal blooms has directed most algicidal bacteria research (Stewart \& Brown 1969, Imai et al. 1993, Doucette et al. 1998, 1999, Lovejoy et al. 1998, Kim et al. 1998, Holmström \& Kjelleberg 1999, Yoshinaga et al. 1999, Nagasaki et al. 2000). Very little is known about algicidal bacteria that affect non-toxic algal blooms. All algicidal species apart from ACEM 32, produced algicidal compounds in both late log phase and stationary phase. Many bacterial secondary metabolites, bioactive and algicidal compounds, are only produced during stationary or late log phase (Fukami et al. 1992, Mikhailov \& Ivanova 1994, Lereclus 2000). 
There is also the question of whether the algicidal activity of these species occurs continuously or episodically in the marine environment. There has been a general assumption that bacteria continuously and simultaneously release their bioactive components in the natural ecosystem. We suggest that some algicidal bacteria may not always exude algicidal components, and may have periods in the natural environment in which they are not producing one or more of their bioactive compounds. The reason for this variation may be environmental or be caused by strain variation. Although no algicidal bacteria in this study produced the quorum sensing homoserine lactones (AHL) according to the Agrobacterium assay, many bioactive environmental bacteria do not have AHL mechanisms; instead, they appear to use an alternative induction pathway (AI-2) which can activate at lower cell concentrations than required for AHL (Bassler 1999, Schauder et al. 2001). This alternative AI-2 mechanism may play a role in switching on algicidal activity for the Gram-negative bacteria once the bacteria reach a specific cell density. The results for the algicidal bacteria indicate moderate to good induction of this second mechanism when compared to the negative control. ACEM 1 demonstrated induction for early log phase and ACEM 21 for mid-log phase. The AI-2 mechanism has been thought to be for bacteria communicating between species rather than AHL. This type of interspecies communication in the marine environment would be a more realistic mechanism of action (Surette \& Bassler 1999). In the marine environment, there is likely to be a greater metabolic benefit for these different bioactive mechanisms to be activated individually or as the bacteria requires, rather than simultaneously and continually.

Gram-positive bacteria do not generally employ AHL as signals. They secrete processed peptide signalling molecules via a dedicated exporter protein (Bassler 1999). For example, in Bacillus subtilis, 2 peptide signals allow the bacteria to control DNA uptake and sporulation. The secretion mechanics of the export of the peptides have not been identified (Bassler 1999). The positive results in the autoinduction experiment for ACEM 32 (B. cereus) and ACEM 22 (Planomicrobium sp.) were likely to be the result of this Grampositive quorum signalling mechanism which may play a role in the bioactive mechanisms in these species.

\section{Algicidal activity}

The bacteria in this study exhibited predatory and species specific algicidal abilities. They also grew well on nutrient-rich media, had very short generation times and high specific growth rates. Because of these particular characteristics, the algicidal isolates, particularly the genera Cellulophaga and Pseudoalteromonas, could be grouped as opportunistic or $r$-strategists (Weinbauer \& Hofle 1998). For example, the growth rates for the algicidal isolates indicated that they could live as attached or free-living bacteria as they would be able to take advantage of a sudden increase in nutrients. Therefore, all algicidal strains have the ability to take advantage of the high summer water temperatures $\left(19^{\circ} \mathrm{C}\right)$ and/or increased nutrients that occur during dinoflagellate blooms at temperatures and salinity conditions typically found in the estuary. In addition, related results from Skerratt (2001) using fluorescent in situ hybridization and the genus and cluster specific probes for Pseudoalteromonas (Pukall et al. 1999) and Class Flavobacteria (Manz et al. 1996), demonstrated that this genus and class were both major contributors to the bacterial community in the estuary during the algal bloom periods.

Achieving a bacterial density high enough to induce lysis of dinoflagellate vegetative cells would be possible if algicidal bacteria were to dominate the bacterial population in the Huon Estuary. Attachment of bacteria to marine snow or algal cells also creates a zone of high bacterial numbers and thus, a greater likelihood of more effective algicidal activity. Highly diffusible compounds such as the algicidal components could become rapidly diluted out. However, in the context of a bloom situation in the estuary this is not as significant when algae and bacteria are closely confined. As Gymnodinium catenatum blooms generally occur in a stable water column in the Estuary (CSIRO Huon Study Team 2000), this lowers the rate of bacterial cells being washed away. The tidal pull of the lower marine water and the flow of the river effectively recirculates the water within the estuary during summer and autumn, and this in turn keeps high levels of dinoflagellates within the estuary (CSIRO Huon Study Team 2000). G. catenatum in particular generally only blooms when the estuary is well stratified and highly stable (CSIRO Huon Study Team 2000). Therefore, it is realistic that the bacteria could stay in the vicinity of the bloom despite the diurnal migration of G. catenatum up and down through the water column.

The swarming capacity and attack of algal cells by ACEM 1 was first observed by Lovejoy et al. (1998) and although not an unusual bacterial ability, the swarming attacks of ACEM 21 and ACEM 1 observed in this study were physically aggressive in comparison with those by ACEM 20, ACEM 4 and ACEM 32. Rapid movement in isolates such as ACEM 21 may also enable the bacteria to more effectively access nutrients in the marine environment and capitalise on patchy nutrient availability. 


\section{Algicidal compounds}

Structural elucidation of algal lytic compounds has remained elusive for over $20 \mathrm{yr}$, despite researchers attempting their isolation, purification and characterisation (Baker \& Herson 1978, Dakhama et al. 1993, Doucette et al. 1998). Part of the difficulty in isolation was the highly polar nature of the compounds and the loss or degradation of the bioactive components when trying to concentrate them or form derivatives. Algicidal compounds and their characteristics vary markedly across the many species of algicidal bacteria (Doucette et al. 1998). The one similarity was that all were highly polar, making them readily diffusible in the marine environment. The compounds can be heat labile (Baker \& Herson 1978) or heat tolerant (Dakhama et al. 1993), of a large (Lee et al. 2000) or small molecular weight (Fukami et al. 1992, Dakhama et al. 1993), made up of a number of compounds or only one, as well as being species specific or non-specific in their mode of action (Doucette et al. 1998). The algicidal compounds in ACEM 1 were small molecular weight $(<300 \mathrm{amu})$, highly polar and heat stable. Algicidal compounds in the other 5 species in this study were also heat tolerant, although all lost activity if left for an extended period of time.

The extracted pigments of the algicidal bacteria were not the algicidal component. Non-pigmented colonies in this study exhibited algicidal activity; however, they were capable of reverting back to their original pigmented state. By contrast, the unpigmented mutants in the study of Egan et al. (2002) were not algicidal but they remained unpigmented. Pigment formation may therefore be associated with algicidal activity, but it does not have to be expressed for the algicidal activity to exist.

\section{CONCLUSION}

For control of algal blooms such as Gymnodinium catenatum, the vegetative cells of this species could be affected in the natural environment by high numbers of algicidal bacteria either by natural means or via human intervention. In practice, many toxic marine algal blooms, unlike freshwater cyanobacterial blooms, occur in open ocean areas and estuaries which are not easily confined. However, the discovery of algicidal bacteria in the marine environment supports increasing recognition that marine bacteria can produce complex secondary metabolites and/or their derivatives. As research continues, it is possible that algicidal species will be found to be more widespread and common in other bacterial genera. The isolation of 5 algicidal species, 3 of which were novel, is beneficial for in- creasing knowledge of bacteria with bioactive potential in the marine environment. Future studies on understanding whether algicidal or bioactive mechanisms switch on and off with different environmental triggers, would be a valuable contribution to knowledge of the ecology of microbial systems.

Acknowledgements. Prof Kjelleberg, staff and students at the Department of Immunology at the University of New South Wales are thanked for their help and use of laboratory facilities. Judi Marshall is thanked for help with algal cultures.

\section{LITERATURE CITED}

Baker KH, Herson DS (1978) Interactions between the diatom Thallasiosira pseudonanna [sic] and an associated Pseudomonad in a mariculture system. Appl Environ Microbiol 35:791-796

Bassler BL (1999) How bacteria talk to each other: regulation of gene expression by quorum sensing. Curr Opin Microbiol 2:582-587

Bassler BL, Wright M, Showalter RE, Silverman MR (1993) Intercellular signalling in Vibrio harveyi-sequence and function of genes regulating expression of luminescence. Mol Microbiol 9:773-786

Blackburn SI, Hallegraeff GM, Bolch CJ (1989) Vegetative reproduction and sexual life cycle of the toxic dinoflagellate Gymnodinium catenatum from Tasmania, Australia. J Phycol 25:577-590

Bligh, EG, Dyer, WM (1959) A rapid method of total lipid extraction and purification. Can J Biochem Physiol 35: 911-917

Bowman JP, Cavanagh J, Austin JJ, Sanderson K (1996) Novel Psychrobacter species from Antarctic ornithogenic soils. Int J Syst Bacteriol 46:841-848

Buck JD, Meyers SP, Leifson E (1963) Pseudomonas (Flavobacterium) piscicida Bein comb nov. J Bacteriol 86: $1125-1126$

Cha C, Gao P, Chen YC, Shaw PD, Farrand SK (1998) Production of acyl-homoserine lactone quorum-sensing signals by gram-negative plant-associated bacteria. Mol Plant-Microbe Interact 11:1119-1129

Clark DJ, Maaløe O (1967) DNA replication and division cycle in Escherichia coli. J Mol Biol 23:99-112

Claus D, Berkeley RCW (1989) Genus Bacillus Cohn 1872 174AL. In: Staley T, Bryant MP, Pfennig N, Holt JG (eds) Bergey's manual of systematic bacteriology, Vol 1. Williams \& Wilkins, Baltimore, p 1105-1137

Commonwealth Scientific and Industrial Research Organisation (CSIRO) Huon Estuary Study Team (2000) Huon estuary study - Environmental research for integrated catchment management and aquaculture. Final report to Fisheries Research and Development Corporation. Project number 96/284 June. CSIRO Division of Marine Research Marine Laboratories, Hobart

Cottrell MT, Kirchman DL (2000) Community composition of marine bacterioplankton determined by 16S rRNA gene clone libraries and fluorescence in situ hybridization. Appl Environ Microbiol 66:5116-5122

Crump BC, Armbrust EV, Baross JA (1999) Phylogenetic analysis of particle-attached and free-living bacterial communities in the Columbia River, its estuary, and the adjacent coastal ocean. Appl Environ Microbiol 65:3192-3204

Dakhama A, de la Noüle J, Lavoie MC (1993) Isolation and 
identification of antialgal substances produced by Pseudomonas aeruginosa. J Appl Phycol 5:297-306

Delong EF, Franks DG, Alldredge AL (1993) Phylogenetic diversity of aggregate-attached vs free living marine bacterial assemblages. Limnol Oceanogr 38:924-934

Doucette GJ, Kodama M, Franca S, Gallacher S (1998) Bacterial interactions with harmful algal bloom species: bloom ecology toxigenesis and cytology. In: Anderson DM, Cembella AD, Hallegraeff GM (eds) Physiological ecology of harmful algal blooms. NATO ASI Series, Vol G41. Springer-Verlag, Berlin,p 619-647

Doucette GJ, McGovern ER, Babinchak JA (1999) Algicidal bacteria active against Gymnodinium breve (Dinophyceae). I. Bacterial isolation and characterisation of killing activity. J Phycol 35:1447-1454

Eberl L (1999) N-acyl homoserine lactone-mediated gene regulation in gram-negative bacteria. Syst Appl Microbiol 22: 493-506

Egan S, Thomas T, Holmström C, Kjelleberg S (2000) Phylogenetic relationship and antifouling activity of bacterial epiphytes from the marine algal Ulva lactuca. Environ Microbiol 2:343-347

Egan S, James S, Kjelleberg S (2002) Identification and characterization of a putative transcriptional regulator controlling the expression of fouling inhibitors in Pseudoalteromonas tunicata. Appl Environ Microbiol 68:372-378

Fandino LB, Riemann L, Steward GF, Long RA, Azam F (2001) Variations in bacterial community structure during a dinoflagellate bloom analyzed by DGGE and 16S rDNA sequencing. Aquat Microb Ecol 23:119-130

Fukami K, Yuzawa A, Nishijima T, Hata Y (1992) Isolation and properties of a bacterium inhibiting the growth of Gymnodinium nagasakiense. Nippon Suisan Gakkaishi 58: 1073-1077

Furuki M, Kobayashi M (1991) Interaction between Chattonella and bacteria and prevention of this red tide. Mar Pollut Bull 23:189-193

Gauthier MJ (1976) Alteromonas rubra sp. nov. a new marine antibiotic-producing bacterium. Int J Syst Bacteriol 24: $459-466$

Gauthier MJ, Breittmayer VA (1979) A new antibiotic producing bacterium from seawater: Alteromonas aurantia sp. nov. Int J Syst Bacteriol 29:366-372

Glöckner FO, Fuchs BM, Amann R (1999) Bacterioplankton compositions of lakes and oceans: a first comparison based on fluorescence in situ hybridisation. Appl Environ Microbiol 65:3721-3726

Grodnitskaya ID, Gukasyan AB (1999) Bacterial diseases of conifer seedlings in forest nurseries of central Siberia. Microbiology 68:189-193

Guillard RRL, Ryther JH (1962) Studies of marine plankton diatoms. I. Cyclotella nana Hustedt and Detonula confervacea (Cleve) Gran. Can J Microbiol 8:229-239

Hammad AMM, El-Mohandes MAO (1999) Controlling Fusarium wilt disease of cucumber plants via antagonistic microorganisms in free and immobilised states. Microbiol Res 154:113-117

Holmström C, Kjelleberg S (1999) Marine Pseudoalteromonas species are associated with higher organisms and produce biologically active extracellular agents. FEMS Microbiol Ecol 30:285-293

Imai I, Ishida Y, Sawayama S, Hata Y (1991) Isolation of a marine gliding bacterium that kills Chattonella antiqua (Raphidophyceae). Nippon Suisan Gakkaishi 57:1409

Imai I, Ishida Y, Hata Y (1993) Killing of marine phytoplankton by a gliding bacterium Cytophaga sp. isolated from the coastal sea of Japan. Mar Biol 116:527-532
Imai I, Ishida Y, Sakaguchi K, Hata Y (1995) Algicidal marinebacteria isolated from northern Hiroshima Bay, Japan. Fish Sci 61:628-636

Imai I, Sunahara T, Nishikawa T, Hori Y, Kondo R, Hiroishi S (2001) Fluctuations of the red tide flagellates Chattonella spp. (Raphidophyceae) and the algicidal bacterium Cytophaga sp. in the Seto Inland Sea Japan. Mar Biol 138: 1043-1049

Joyce EA, Bassler BL, Wright A (2000) Evidence for a signalling system in Helicobacter pylori: detection of a LuxSencoded autoinducer. J Bacteriol 182:3638-3643

Kim MC, Yoshinaga I, Imai I, Nagasaki K, Itakura S, Ishida Y (1998) A close relationship between algicidal bacteria and termination of Heterosigma akashiwo (Raphidophyceae) blooms in Hiroshima bay Japan. Mar Ecol Prog Ser 170: 25-32

Kondo R, Imai I, Fukami K, Minami A, Hiroishi S (1999) Phylogenetic analysis of algicidal bacteria (Family Flavobacteriaceae) and selective detection by PCR using a specific primer set. Fish Sci 65:432-435

Lee SO, Kato J, Takiguchi N, Kuroda A, Ikeda T, Mitsutani A, Ohtake H (2000) Involvement of an extracellular protease in algicidal activity of the marine bacterium Pseudoalteromonas sp. Strain A28. Appl Environ Microbiol 66: 4334-4339

Lereclus D, Agaisse H, Grandvalet C, Salamitou S, Gominet M (2000) Regulation of toxin and virulence gene transcription in Bacillus thuringiensis. Int J Med Microbiol 290: 295-299

Lovejoy C, Bowman JP, Hallegraeff GM (1998) Algicidal effects of a novel marine Pseudoalteromonas isolate (class proteobacteria gamma subdivision) on harmful algal bloom species of the genera Chattonella Gymnodinium and Heterosigma. Appl Environ Microbiol 64:2806-2813

Manz W, Amann R, Ludwig W, Van Canneyt M, Schleifer KH (1996) Application of a suite of 16S rRNA specific oligonucleotide probes designed to investigate bacteria of the phylum Cytophaga-Flavobacterium-Bacteriodes in the natural environment. Microbiology 142:1097-1106

Marmur J, Doty P (1962) Determination of the base composition of deoxyribonucleic acid from its thermal denatuartion temperature. J Mol Biol 5:109-118

McCarthy SA, Johnson RM, Kakimoto D (1994) Characterisation of an antibiotic produced by Alteromonas luteoviolacea Gauthier 198285 isolated from Kinko Bay Japan. J Appl Bacteriol 77:426-432

Mikhailov VV, Ivanova EP (1994) Bacteria of the genus Alteromonas: Systematics and biologically active compounds. Russ J Mar Biol 20:129-135

Mitsutani A, Takesue K, Kirita, M, Ishida Y (1992) Lysis of Skeletonoma costatum by Cytophaga sp. isolated from the coastal water of the Ariake Sea. Nippon Suisan Gakkaishi 58:2158-2167

Nagai S, Imai I (1998) Killing of a giant diatom Coscinodiscus wailesii Granby by a marine bacterium Alteromonas sp. Isolated from the Seto Inland Sea of Japan. In: Reguera B, Blanco J, Fernández ML, Wyatt T (eds) Harmful algae. Xunta de Galicia and Intergovernmental Oceanographic Commission of UNESCO, Vigo, p 402-405

Nagasaki K, Yamaguchi M, Imai I (2000) Algicidal activity of a killer bacterium against the harmful red tide dinoflagellate Heterocapsa circularisquama isolated from Ago Bay Japan. Nippon Suisan Gakkaishi 66:666-673

Parker N (2002) Sexual lifestages of dinoflagellates. PhD thesis, University of Tasmania, Hobart

Pinhassi J, Hagström A (2000) Seasonal succession in marine bacterioplankton. Aquat Microb Ecol 21:245-256 
Pirt SJ (1975) Principles of microbe and cell cultivation. Halsted Press, New York, p 5-35

Pruss BM, Dietrich R, Nibler B, Martlbauer E, Scherer S (1999) The haemolytic enterotoxin HBL is broadly distributed among species of the Bacillus cereus group. Appl Environ Microbiol 65:5436-5442

Pukall R, Päuker O, Buntefu BD, Ulrichs G and 5 others (1999) High sequence diversity of Alteromonas macleodii related cloned and cellular 16S rDNA from a Mediterranean seawater mesocosm experiment. FEMS Microbiol Ecol 28: 335-344

Riemann L, Steward GF, Azam F (2000) Dynamics of bacterial community composition and activity during a mesocosm diatom bloom. Appl Environ Microbiol 66:578-587

Schauder S, Shokat K, Surette MG, Bassler BL (2001) The LuxS family of bacterial autoinducers: biosynthesis of a novel quorum-sensing signal molecule. Mol Microbiol 41: 463-476

Skerratt JH (2001) Bacterial and algal interactions in a Tasmanian Estuary. PhD thesis, University of Tasmania, Hobart

Stewart JR, Brown RM (1969) Cytophaga that kills or lyses algae. Science 164:1523-1524

Surette MG, Bassler BL (1998) Quorum sensing in Escherichia coli and Salmonella typhimurium. Proc Natl Acad Sci USA 95:7046-7050

Surette MG, Bassler BL (1999) Regulation of autoinducer production in Salmonella typhimurium. Mol Microbiol 31: 585-595

Editorial responsibility: Otto Kinne (Editor), Oldendorf/Luhe, Germany
Toncheva-Panova T, Ivanova J (2000) Influence of physiological factors on the lysis effect of Cytophaga on the red microalga Rhodella reticulata. J Appl Microbiol 88: $358-363$

Weinbauer MG, Hofle MG (1998) Distribution and life strategies of two bacterial populations in a eutrophic lake. Appl Environ Microbiol 64:3776-3783

White DC, Bobbie RJ, Herron JS, King JD, Morrison SJ (1979) Biochemical measurements of microbial biomass and activity from environmental samples. In: Costerton JW, Colwell RR (eds) Nature of aquatic bacteria: enumeration, activity and ecology. ASTM STP 694, American Society of Test Materials. American Society for Microbiology, Washington, DC

Yoshinaga I, Kawai T, Takeuchi T, Ishida Y (1995) Distribution and fluctuation of bacteria inhibiting the growth of marine red tide phytoplankton Gymnodinium mikimotoi in Tanabe bay (Wakayama pref, Japan). Fish Sci 61: $780-786$

Yoshinaga I, Kim MC, Katanozaka N, Imai I, Uchida A, Ishida Y (1998) Population structure of algicidal marine bacteria targeting the red tide forming alga Heterosigma akashiwo (Raphidophyceae), determined by restriction fragment length polymorphism analysis of the bacterial 16S rRNA genes. Mar Ecol Prog Ser 170:33-44

Yoshinaga I, Kim MC, Tsujino K, Nakajima M, Yamamoto K, Uchida A, Ishida Y (1999) Ribotype analysis of HAKB (Heterosigma akashiwo-killing bacteria) strains isolated during termination period of a $H$. akashiwo bloom occurred in Osaka Bay. Fish Sci 65:786-787

Submitted: March 13, 2002; Accepted: July 16, 2002

Proofs received from author(s): November 5, 2002 